\title{
Major Prion Protein
}

National Cancer Institute

\section{Source}

National Cancer Institute. Major Prion Protein. NCI Thesaurus. Code C71456.

Major prion protein (253 aa, $\sim 28 \mathrm{kDa}$ ) is encoded by the human PRNP gene. This protein is bound to the membrane by a glycosylphosphatidylinositol-anchor and it plays a role in the pathology and transmission of human prion diseases. 